\title{
Cardiovascular Risk in People Living with HIV/AIDS: Implications for Health Care
}

\section{Renata Karina Reis* and Elizabete Santos Melo}

College of Nursing, University of São Paulo, WHO Collaborating Centre for Nursing Research Development Postgraduate Program in Fundamental Nursing Ribeirão Preto $S P$, Brazil

In the past 30 years, medical advances for those with human immunodeficiency virus (HIV) have reduced morbidity and mortality to extend life with the continued development of new therapies [1]. The introduction of Highly Active Antiretroviral Therapy (HAART) has resulted in a more effective infection control, immunity restoration and reduction of morbidity and mortality, transforming AIDS into a chronic disease.

Such advances, however, are now faced with new challenges, among them stand out the need to expand access to ART and improve adherence to this therapy and control the undesirable effects of this therapy, and the need to prevent, recognize and manage emerging comorbidities that in the pre-antiretroviral therapy (HAART), had no great expression [2].

With this new paradigm, in recent years the cardiovascular risk of people living with HIV/aids has become the focus of researchers studies in different regions and levels of development [3-8]. The presence of other co-morbidities such as hypertension, diabetes, dyslipidemia and obesity, is also common in this population, thereby increasing the risk for developing cardiovascular diseases $[9,10]$ which have emerged as an important cause of morbidity and mortality in adults living with HIV/AIDS [7].

The evidence demonstrated by cohort studies have shown that people living with HIV are at risk for cardiovascular diseases 1.5 to 2 times higher than the general Population $[11,12]$

The traditional paradigm to explain this increased risk includes the effect of HIV infection itself, since they have persistent immune and inflammatory activation, and the effects of antiretroviral therapy, which causes dyslipidemia, ectopic fat accumulation (lipodystrophy) and diabetes or insulin resistance. As well as factors such as smoking, coinfection and drug use. Once such factors contribute to the formation of calcified coronary plaques $[7,13]$.

Thus, the study of Van Vonderen et al. showed that people living with HIV/aids have a higher prevalence and degree of premature coronary atherosclerosis compared to the general population. Similarly, cross-sectional studies have shown that HIV-infected individuals have provided significant risk for acute myocardial infarction (AMI), according to the Framingham scores $[7,14]$.

Taken together, these data suggest a new mechanistic paradigma for atherogenesis in HIV disease, and potential strategies for reducing inflammation and atherosclerosis [13]. These strategies would minimize the classic risk factors such as smoking cessation, blood pressure control, correction of insulin resistance and dyslipidemia, obesity reduction and use of less-toxic antiretroviral therapy. Viral burden and latency can be reduced through earlier initiation of antiretroviral therapy and use of intensification strategies [13].

Currently, HIV/aids is considered a chronic condition and is associated with increased risk of $50 \%$ of acute myocardial infarction in addition to the recognized risk factors [12] which may have impact on morbidity and mortality of these individuals. By the time discussing the importance of early antiretroviral therapy for people living with HIV/ aids is important not to lose sight of the impact of increased longevity of these individuals in pursuit of development and implementation of public policies to modify a setting that has sociocultural factors which lead to excessive consumption of foods high in calories by population, physical inactivity and, consequently, the development of obesity and diabetes associated with excess dietary salt. These factors contribute to the occurrence of hypertension and are decisive for the high prevalence of CVD [15].

In addition, the recognition of cardiovascular risk factors among people living with HIV/aids can contribute to the organization of health services in the sense that they have the opportunity to seek interventions aimed at the prevention of CVD through orientation lifestyle changes.

Despite this scenario few studies in Brazil have been conducted to evaluate the risk factors of these individuals.

These indicators point to the need for studies that contribute to the implementation of interventions for the prevention and treatment of cardiovascular risk factors in people living with HIV/aids, as these require interdisciplinary care. In addition, the results may contribute also to structure and strengthen the urgency and emergency care of these individuals in the network of health care.

\section{References}

1. Hester EK (2012) HIV medications: an update and review of metabolic complications. Nutr Clin Pract 1: 51-64.

2. Marins JR, Jamal LF, Chen SY, Barros MB, Hudes ES, et al. (2003) Dramatic improvement in survival among adult Brazilian AIDS patients. AIDS 17: 16751682.

3. Cahn P, Leite O, Rosales A, Cabello R, Alvarez CA, et al. (2010) Metabolic profile and cardiovascular risk factors among Latin American HIV-infected patients receiving HAART. Braz J Infect Dis 2: 158-166.

4. Edwards-Jackson N, Kerr S, Tieu H, Ananworanich J, Hammer S, et al. (2011) Cardiovascular risk assessment in persons with HIV infection in the developing world: comparing three risk equations in a cohort of HIV-infected Thais. HIV Medicine 8: 510-515

5. Palella FJ, Phair JP (2011) Cardiovascular disease in HIV infection. Curr Opin HIV AIDS 4: 266-271.

*Corresponding author: Renata Karina Reis, College of Nursing, University of São Paulo, Ribeirão Preto, SP, Brazil, Tel: +55-16-3315-34-21; E-mail: rkreis@eerp.usp.br

Received September 26, 2015; Accepted October 16, 2015; Published October 25,2015

Citation: Reis RK, Melo ES (2015) Cardiovascular Risk in People Living with HIV AIDS: Implications for Health Care. J AIDS Clin Res 6: 513. doi:10.4172/21556113.1000513

Copyright: ( 2015 Reis RK, et al. This is an open-access article distributed under the terms of the Creative Commons Attribution License, which permits unrestricted use, distribution, and reproduction in any medium, provided the original author and source are credited. 
Citation: Reis RK, Melo ES (2015) Cardiovascular Risk in People Living with HIV/AIDS: Implications for Health Care. J AIDS Clin Res 6: 513. doi:10.4172/2155-6113.1000513

6. Vilela FD, Lorenzo AR, Tura BR, Ferraiuoli GI, Hadlich M, et al. (2011) Risk of coronary artery disease in individuals infected with human immunodeficiency virus. Braz J Infect Dis 6: 521-527.

7. Cioe PA Crawford SL, Stein MD (2014) Cardiovascular risk-factor knowledge and risk perception among HIV-infected adults. J Assoc Nurses AIDS Care 1: 60-69.

8. Tripathi A, Liese AD, Winniford MD, Jerrell JM, Albrecht $H$, et al. (2014) Impact of clinical and therapeutic factors on incident cardiovascular and cerebrovascular events in a population-based cohort of HIV infected and nonHIV-infected adults. Clinical Cardiology 9: 517-522.

9. Kaplan RC, Kingsley LA, Sharrett AR, Li X, Lazar J,Mateen FJ et al. (2013) Long-term predictive value of the Framingham Risk Score for Stroke in HIVpositive vs HIV-negative men. Neurology 24: 2094-102.

10. Mateen FJ, Post WS, Sacktor N, Abraham AG, Becker JT, et al. (2013) Longterm predictive value of the Framingham Risk Score for Stroke in HIV-positive vs HIV-negative men. Neurology 24: 2094-2102.
11. Triant VA, Lee H, Hadigan C, Grinspoon SK(2007) Increased acute myocardial infarction rates and cardiovascular risk factors among patients with human immunodeficiency virus disease. J Clin Endocrinol Metab 7: 2506-2512.

12. Freiberg MS, Chang CC, Kuller LH, Skanderson M, Lowy E, et al. (2013) HIV infection and the risk of acute myocardial infarction. JAMA Internat Med 8: 614622.

13. Grispoon SK (2014) Cardiovascular disease in HIV: traditional and nontraditional risk factors. Topics in Antiviral Medicine 4: 676-679.

14. Glass TR, Ungsedhapand C, Wolbers M, Weber R, Vernazza PL, et al. (2006) Prevalence of risk factors for cardiovascular disease in HIV infected patients over time: the Swiss HIV Cohort Study. HIV Med 7: 404-410.

15. Simão AF, Précoma DB, Andrade JP, Correa-Filho H, Saraiva JFK, et al. (2014) I Cardiovascular Prevention Guideline of the Brazilian Society of Cardiology. Arq Bras Cardiol 5: 420-431. 